\title{
PREFACE
}

\section{FREDERICK LAW OLMSTED AND THE SENSE OF PLACE}

No two places on Earth are the same. Each has its unique, prevailing atmosphere, its distinctive character, its spirit of place, its genius loci. The perception of the genius loci, which fully engages the intellectual, emotional, and sensual in a single moment, is what John Dewey (1859-1952) defined in Art as Experience (1934) as a peak experience. This universal character of the impression of place and space is governed first by what is perceived and then subjectively processed by the individual's thinking, judgment, associations, and understanding. ${ }^{1}$

The genius loci-natural, modified, or built-is the framework upon which a city or town aligns. For example, the main street of Tepoztlan, Mexico, is aligned on a small Aztec pyramid tucked high in the mountain above it, while the great pyramids of Teotihuacan are aligned on high mountains on the distant horizon. A sense of place can create a feeling of home in people's hearts: a good, comfortable experience of familiarity, representing their specific place on the planet. Early urban inhabitants chose a patron goddess, god, saint, or nymph as a cultural shorthand for all or part of a location's sense of place, giving rise to the term genius loci, spirit of place.

Sense of place is the singularly most important thing for a planner to keep in mind. Sensitivity to it is the first and ultimate responsibility of planners and architects. ${ }^{2}$

Being the only design discipline to install living things, landscape architecture is arguably the most elevated field of design. The master landscape architect is a rarer commodity than the master architect, engineer, planner, or designer. Among landscape architects, Frederick Law Olmsted (1822-1903) stands out for directly influencing the look of an entire continent-North America. $^{3}$

Accompanying his father on annual tours in search of the picturesque, Olmsted, by age sixteen, had been up the Hudson River, to the Adirondacks, and to Niagara Falls. He read the late eighteenth-century English landscape architects, travelers, and theorists, notably
Uvedale Price's An Essay on the Picturesque (1794), Humphry Repton's Sketches and Hints on Landscape Gardening (1795) and The Theory and Practice of Landscape Gardening (1803), and William Gilpin's Remarks on Forest Scenery, and Other Woodland Views (Related Chiefly to Picturesque Beauty) (1790). He so treasured these books that he ensured his apprentices read them, "as a student of Law would read Blackstone."

Olmsted understood how a mind perceiving beautiful cues from a landscape affected a person. Whether or not the viewer was aware of its workings, he thought, a landscape relaxed faculties made tense by psychological strain and an abrasive built environment. He knew that if the experience was "good," it was because of a perception of holism, of nature, of the divine. As if painting a tableau, Olmsted enhanced the sense of space through sequential views. He composed broad spaces of glistening greensward punctuated by groves of trees, producing narratives and unfolding stories. He used indistinct boundaries to suggest infinity, nature, abundance, and freedom. He planted more lushly than nature itself.

Although Olmsted's method was straightforward, mystery has been attached to it. Olmsted manipulated foregrounds, midgrounds, and backgrounds to deepen perspective; he formed ground cover, shrubs, and trees into garden "rooms." He devised effects of shadow and light to enhance the feeling of nature and its mystery. He amplified the genius loci of each part of the parks he worked on, sensitively providing visual cues to engender experiences of the sublime and the beautiful.

Olmsted believed that the urban artist's goal was to make his hand invisible, and concealing artifice was the art Olmsted practiced. For the landscape experience to ring organic and true, Olmsted subtly shaped his work to appear so natural that one would think of it as having always been there. He liberated users to get lost in his spaces, while endowing them with the confidence that they were on a safe path of delight. He simultaneously 
ensured the design's timelessness and perpetuated its intent by means of durable construction. The result was a man-made nature that uniquely combines richness and wildness in a unified composition. ${ }^{5}$

Olmsted considered it a scientific fact that the occasional change of air and contemplation of natural scenes supported mental vigor and physical health. Believing that aesthetic sensibility was a way to channel American society toward a more civilized, healthful state, Olmsted's vision of a city contained parks, and he treated parkways and boulevards connecting to and through suburbs as their extensions. ${ }^{\circ}$

Beginning in 1857 with the design for Central Park in New York City, Frederick Law Olmsted, his sons, and his successor firms created a legacy of some of the world's most important parks: Prospect Park in Brooklyn; Boston's Emerald Necklace; Biltmore Estate in Asheville, North Carolina; Mount Royal in Montreal; and the grounds of the US Capitol and White House, as well as Washington Park, Jackson Park, and the World's Columbian Exposition of 1893 in Chicago. He also played an influential role in the creation of the National Park Service.

Olmsted's parks reflected humanistic, social, and artistic values that are endowed with and express the common good. Critical of designs which focused on displays of novelty, fashion, or virtuoso inclinations, Olmsted silently championed through his parks the discourse of Price, Repton, and Gilpin on ideas of the sublime and the beautiful that shaped the Romantic and Modernist worlds. Through urban landscapes that harmonize with and augment their sense of place, his work conveys nineteenth-century Romantic sensibilities in an Enlightenment framework. It reflects a vision of communities and society in which a commitment to the experience of beauty is key.

Olmsted's attitude and legacy reflect the most important things to bring to the design of cities and places: to balance our aesthetic experience of the sublime and the beautiful and to constantly work from the spirit and ambiance of places-their genius loci-because no two places on Earth are the same. 